\title{
The Effectiveness of Vaccination Against The Spread of COVID-19 with SEIR Mathematical Modeling in Gowa District
}

\author{
Syafruddin Side ${ }^{1}$, Putri Kharina Mahathir Hulinggi ${ }^{2}$, Husnul Khatimah Syam ${ }^{3}$, Muhammad Irfan ${ }^{4}$, \\ Andi Gagah Palarungi Taufik ${ }^{5}$ \\ 1,2,3,5 Mathematics Department, Universitas Negeri Makassar, Indonesia \\ ${ }^{4}$ Statistics Department, Universitas Negeri Makassar, Indonesia
}

\begin{tabular}{l}
\hline Article Info \\
\hline Article history: \\
Received : $08-18-2021$ \\
Revised : 10-15-2021 \\
Accepted : $10-18-2021$
\end{tabular}

Keywords:

SEIR Model;

COVID-19;

Vaccines;

Pandemic;

Basic Reproduction Number.

\section{ABSTRACT}

The spread of disease in epidemic range, endemic range, as well as in the pandemic range that is spreading of the disease can be stopped with getting vaccinated. The vaccines that are effective and efficient can be the missile that stopped this Covid-19 pandemic. The aim of this research is to (1) know the mapping model of mathematics SEIR in distributing vaccines toward the spread of Covid-19 in Kabupaten Gowa, (2) know the analysis and model simulation of mathematics SEIR in distributing vaccine toward the spread of Covid-19 in Kabupaten Gowa, also (3) know the impact of distributing vaccine toward the spread of Covid-19 in Kabupaten Gowa. The method we used is the literature review, the collecting data obtained by an interview and documentation review. The research result discovered that the model of mathematics SEIR is used to describe the distribution of vaccines toward the spread of Covid-19 in Kabupaten Gowa. The analysis and simulation results model of mathematics SEIR showed that the higher vaccines effectiveness and the number of the population in Kabupaten Gowa that already had vaccinated is higher, then showed no more spreads of Covid-19 and the pandemic is over.

Accredited by Kemenristekdikti, Decree No: 200/M/KPT/2020 DOI: https://doi.org/10.30812/varian.v5i1.1404

Corresponding Author:

This is an open access article under the CC BY-SA license.

Syafruddin Side,

Department of Mathematics, Universitas Negeri Makassar.

Email: syafruddin@unm.ac.id

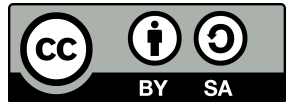

\section{A. INTRODUCTION}

The outbreak of novel coronavirus disease, COVID-19, caused by the new coronavirus 2019-nCoV that is now officially designated as severe acute respiratory syndrome-related coronavirus SARS-CoV-2, represents a pandemic threat to global public health (Liu et al., 2020). Based on the data of the World Health Organization on 6 February 2021, recorded the number of active cases in the whole world who are infected by the COVID-19 virus are 104.956.439 and 2.290.488 the number of death (WHO, 2021).

COVID-19 virus has already spread throughout all of the provinces in Indonesia. Based on the Komite Penanganan COVID-19 dan Pemulihan Ekonomi Nasional data obtained from www.covid19.go.id on 6 February 2021, registered that Indonesia experienced additional cases, which are 12.156 positive cases, 12.204 recovered, and 191 died, so that the number of COVID-19 exposed cases confirmed as many 1.147.010 positive cases, 939.184 recovered, and 31.393 died (KPCN, 2021).

The spread of COVID-19 in Sulawesi Selatan, especially in Kabupaten Gowa based on the data of Sulsel Tanggap Covid19 obtained from www.covid19.sulselprov.go.id the active cases confirmed as many 3.973 cases, with 1471 asymptomatic, 2.502 symptomatic, 47.862 recovered, and 805 dead, so that the number of confirmed cases were 52.640 cases per February 2021 (Sulsel Tanggap Covid-19, 2021). 
The high death cases of COVID-19 caused every country various people seemly active in contributing to find the right solutions handling this problem, including the mathematical modelling expert from various country. Mathematical modelling is one of the main tools in epidemic planning which can help in making it easier to solve the COVID-19 problem. Through the mathematical modelling, it can be identified the transmission connect of COVID-19 by the epidemiology parameters, which can help in planning and considering the steps of proper control (Resmawan et al., 2021). The main focus of this research is the impact of distributing vaccines toward the spread of COVID-19 and mathematics SEIR Model. The aim of this research is to (1) know the mapping model of mathematics SEIR in distributing vaccines toward the spread of Covid-19 in Kabupaten Gowa, (2) know the analysis and model simulation of mathematics SEIR in distributing vaccine toward the spread of Covid-19 in Kabupaten Gowa, also (3) know the impact of distributing vaccine toward the spread of Covid-19 in Kabupaten Gowa.

The existence of the transmission of the disease either within outbreak, epidemic, even pandemic that the spread of the disease can be stopped with vaccinated. This is supported by the research done by (Aulia et al., 2016) with title "Pemodelan Matematika Epidemi Influenza dengan Memperhatikan Peluang Keberhasilan Vaksinasi dan Kekebalan Tetap" stated that there was no possibility the influenza epidemic will be widespread because it has already been carried out by the precautions in the form of vaccinations with certain immunity; and the research done by (Ophinni et al., 2020) with title " COVID-19 Vaccines: Current Status and Implication for Use in Indonesia" stated that the effective and efficient of vaccines will be the bullet that can end the pandemic of COVID-19; as well as the research done by (Abdy et al., 2021) with An SIR Epidemic Model for COVID-19 Spread with Fuzzy Parameter: The Case of Indonesia stated that vaccinated and application of health protocols having a significant effect on slowing or stopping the transmission of COVID-19 in Indonesia.

Research using mathematics SEIR Model has been done by (Annas et al., 2020) that focused on the transmission of COVID-19 in Indonesia. Until now, there is no study or research that relates to the mathematical SEIR Model with the impact of distributing vaccines toward the spread of COVID-19 problem specifically. Therefore, this research is combining the problem of distributing vaccines toward the spread of COVID-19 in populations of Kabupaten Gowa with mathematical SEIR Model to find the rate of the vaccination effects toward the number of COVID-19 cases in Kabupaten Gowa.

\section{B. LITERATURE REVIEW}

\section{COVID-19}

The infected of corona virus called Coronavirus Disease 2019 (COVID-19) is an infectious disease which caused by one of the species of coronavirus, which is SARS-CoV-2 that firstly founded in The Wuhan City, China on December 2019 (Sifriyani and Rosadi, 2020).

On this age, the spread of SARS-CoV-2 from human to human become the main transmission source so that the spread become more aggressive. The transmission of SARS-CoV-2 from the symptomatic patient can be happened by the droplets that are spitted out when coughing, talking, and sneezing (Han and Yang, 2020).

The COVID-19 patient has several symptoms, such as fever, dry cough, and exhaustion at the very first stage, and then can cause an expansion of an acute respiratory distress syndrome, a respiratory failure, a shock, and many fatal organs failure. The result of the researches shows that the patient with light symptoms needed at least one week or more than that to recover, while the patient with heavy symptoms gradually experiences a respiratory failure which can lead to death. Because of the high level of transmission, WHO decided this case to be a pandemic since early 2020. Even the spread of COVID-19 higher than the spread of SARS-CoV and MERS-CoV (Resmawan et al., 2021).

\section{COVID-19 Vaccines}

The word vaccine is derived from a Latin word Vaccinae, is made by the Variolae vaccinae bacteria was being demonstrated in 1798 to prevent the impact of smallpox in human. The word vaccine recently used in biological preparations and material production that uses living things that can be increase the immunity to battle the disease, to prevent (prophylactic vaccines), or therapeutic vaccines (Ophinni et al., 2020).

Vaccines can prevent and protect from the infection attack and the disease when being founded on a certain disease, especially at the population that are easily being attacked. On the pandemic 2019-nCoV context, vaccines can help to control and decrease from the transmission by creating the herd immunity concept with the intention of protecting ourselves from the transmission (Pang et al., 2020).

The need to develop the vaccines rapidly against the SARS-CoV-2 virus is higher these past months caused by the number 
of COVID-19 patient keep increasing day by day. Every researcher all over the world in every sector, such as geneticist and biological structures help each other to develop this vaccine (Afifah, 2021).

\section{SEIR Epidemic Model}

The impact of distributing vaccines toward the spread of COVID-19 problem is divided by four epidemic model classes, which are S, E, I, and R. Susceptible (S) is the healthy population but potentially infected by this disease, Exposed (E) is the population that are started to become infected by this disease, Infected (I) is the population that are infected and can possibly being recovered from this disease, Recover $(\mathrm{R})$ is the population that are recovered and invulnerable from the infection of this disease. The epidemic SEIR Model is presented in Figure 1.

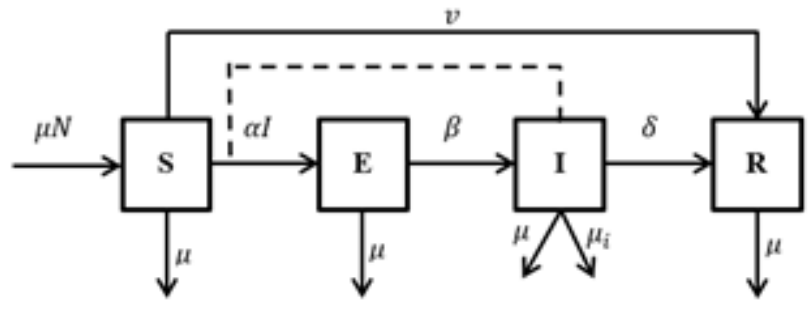

Figure 1. The Scheme of Mathematics SEIR Model

Source: (Annas et al., 2020)

Figure 1 can be interpreted as follows:

$$
\begin{aligned}
& \frac{d S}{d t}=\mu N-(\alpha I+\mu+v) S \\
& \frac{d E}{d t}=\alpha I S-(\beta+\mu) E \\
& \frac{d I}{d t}=\beta E-\left(\mu_{i}+\delta+\mu\right) I \\
& \frac{d R}{d t}=\delta I+v S-\mu R \\
& \text { with } N=S+E+I+R .
\end{aligned}
$$

\section{RESEARCH METHOD}

The SEIR mathematical modelling on the impact of distributing vaccines toward the spread of COVID-19 is a theoretical study. This research is done in May to July 2021. The collecting data is done with interview and documentation study. The collecting data method by the interview was carried out directly by the researchers in the form of questioning with the informant. Meanwhile the collecting data method through documentation study is conducted by collecting secondary data obtained from www.covid19.sulselprov.go.id which originated in the Government of Sulawesi Selatan data and m.andrafarm.com which reports the data from pusatkrisis.kemkes.go.id, covid19.go.id, covid19.bnpb.go.id, and the other sources that attaching the daily cases of COVID-19 in Kabupaten Gowa. The first step done in this study is building a mathematical SEIR Model (Annas et al., 2020) by collecting the information and data to determine the limits of assumptions and parameters of the SEIR Model, then determine the flow diagram of SEIR Model based on the assumptions and parameters that have been set (Abdy et al., 2021). Furthermore, determine the free-disease equilibrium points of COVID-19 toward the distributing vaccines in Kabupaten Gowa and endemic equilibrium point of COVID-19 toward the distributing vaccines in Kabupaten Gowa, then analysing the stability of SEIR Model by determining the eigen values from the differential equations system from the models that have been designed, then do research of the stability of the free-disease equilibrium points of COVID-19 toward the distributing vaccines in Kabupaten Gowa and endemic equilibrium point of COVID-19 toward the distributing vaccines in Kabupaten Gowa, and determine the basic reproduction number $R_{0}$. The last step is knowing the impact of distributing vaccines toward the spread of COVID-19 in Kabupaten Gowa through numerical simulations with help of Maple 18 software from the SEIR Model that have been designed, then draw the conclusion.

\section{RESULT AND DISCUSSION}

\section{SEIR Model for The Impact of Distributing Vaccines Toward The Spread of COVID-19}

The mathematics SEIR Model about the impact of distributing vaccines toward the spread of COVID-19 is divided by four population classes, which are Susceptible (S), Exposed (E), Infected (I), and Recovered (R). The individual at the Infected 
class can be able to make the other individuals infected. The change that happened in each human population on the impact of distributing vaccines toward the spread of COVID-19 for SEIR model is presented in Figure 2 and the definitions of the variables in the model are shown in Table 1.

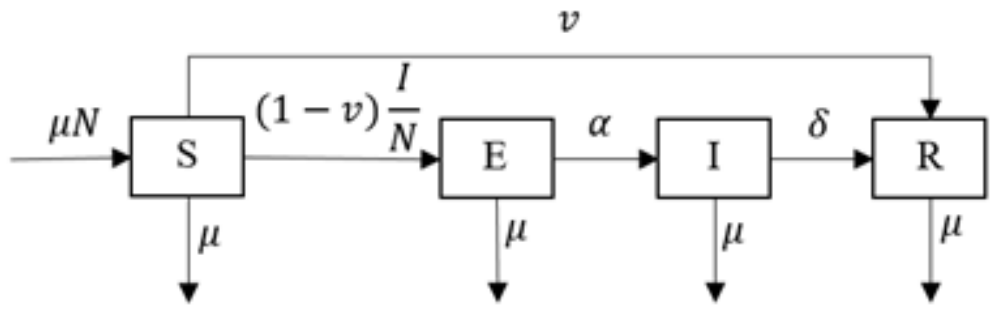

Figure 2. The Mathematics SEIR Model of Distributing Vaccines Toward The Spread of COVID-19

Table 1. Definition of Variables and Parameters

\begin{tabular}{ll}
\hline Variables / Parameters & Definition \\
\hline $\mathrm{S}$ & Number of Suspected populations \\
$\mathrm{E}$ & Number of Exposed populations \\
$\mathrm{I}$ & Number of Infected populations \\
$\mathrm{R}$ & Number of Recovered populations \\
$\mathrm{N}$ & Number of human populations in Kabupaten Gowa 2021 \\
$\alpha$ & The rate of positive cases each day in Kabupaten Gowa 2021 \\
$\delta$ & The rate of recovered people each day in Kabupaten Gowa 2021 \\
$\mu$ & The rate of birth/death population \\
$\mathrm{v}$ & The impact of giving vaccines toward the population in S \\
\hline
\end{tabular}

Based on the population scheme in Figure 2, the rate of change in the number of people Suspected, Exposed, Infected, and Recovered over time in the mathematical SEIR model can be interpreted as follows:

$$
\begin{aligned}
\frac{d S}{d t} & =\mu N-\left(\mu+v+(1-v) \frac{I}{N}\right) S \\
\frac{d E}{d t} & =\left((1-v) \frac{I}{N}\right) S-(\alpha+\mu) E \\
\frac{d I}{d t} & =\alpha E-(\delta+\mu) I \\
\frac{d R}{d t} & =v S+\delta I-\mu R
\end{aligned}
$$

Let $S=\frac{S}{N} ; E=\frac{E}{N} ; I=\frac{I}{N} ; R=\frac{R}{N}$, simplified model becomes:

$$
\begin{aligned}
\frac{d S}{d t} & =\mu-(\mu+v+(1-v) I) S \\
\frac{d E}{d t} & =(1-v) I S-(\alpha+\mu) E \\
\frac{d I}{d t} & =\alpha E-(\delta+\mu) I \\
\frac{d R}{d t} & =v S+\delta I-\mu R
\end{aligned}
$$

\section{Analysis SEIR Model on The Impact of Distributing Vaccines toward The Spread of COVID-19}

a. Equilibrium Point Analysis

Based on the equations (5)-(8), stability analysis is carried out to determine the disease-free equilibrium point and endemic equilibrium point. To determine the two equilibrium points, each equation in equations (5)-(8), must be equal to 
zero, or

$\frac{d S}{d t}=0 ; \frac{d E}{d t}=0 ; \frac{d I}{d t}=0 ; \frac{d R}{d t}=0$

Thus obtained:

$$
\begin{array}{r}
\mu-(\mu+v+(1-v) I) S=0 \\
(1-v) I S-(\alpha+\mu) E=0 \\
\alpha E-(\delta+\mu) I=0 \\
v S+\delta I-\mu R=0
\end{array}
$$

b. Free-Disease Equilibrium Point

The free-disease equilibrium point is a condition where there are no more COVID-19 vaccines distributions, then:

$$
E=I=0
$$

Based on the equation (9), then:

$$
\begin{array}{r}
\mu-(\mu+v) S=0 \\
S=\frac{\mu}{\mu+v}
\end{array}
$$

Based on the equation (12), then:

$$
\begin{gathered}
v S-\mu R=0 \\
R=\frac{v}{\mu+v}
\end{gathered}
$$

Thus, the free-disease equilibrium point for COVID-19 is:

$$
K_{0}=(S, E, I, R)=\left(\frac{\mu}{\mu+v}, 0,0, \frac{v}{\mu+v}\right)
$$

c. Endemic Equilibrium Points

Endemic equilibrium points are used to indicate the possibility of the spread of the disease. Because in endemic conditions and disease spread, then the population $S \neq 0, E \neq 0, I \neq 0, R \neq 0$. Based on the equation (9)-(12), thus obtained:

$$
\begin{aligned}
S^{*} & =\frac{(\alpha+\mu)(\delta+\mu)}{(1-v) \alpha} \\
E^{*} & =\frac{(\delta+\mu)(\mu(1-v) \alpha+(\mu+v)(\alpha+\mu)(\delta+\mu)}{\alpha(1-v)(\alpha+\mu)(\delta+\mu)} \\
I^{*} & =\frac{\mu(1-v)-(\mu+v)(\alpha+\mu)(\delta+\mu)}{(1-v)(\alpha+\mu)(\delta+\mu)} \\
R^{*} & =\frac{v(\alpha+\mu)^{2}(+)^{2}+(1-v) \alpha \delta \mu-(v+\mu)(\alpha+\mu)(\delta+\mu) \alpha \delta}{(1-v)(\alpha+\mu)(\delta+\mu) \alpha \mu}
\end{aligned}
$$

Then, the equilibrium points of endemic are:

$$
K_{e}=\left(\begin{array}{c}
K_{e}=\left(S^{*}, E^{*}, I^{*}, R^{*}\right) \\
\frac{(\alpha+\mu)(\delta+\mu)}{(1-v) \alpha}, \frac{(\delta+\mu)(\mu(1-v) \alpha+(\mu+v)(\alpha+\mu)(\delta+\mu)}{\alpha(1-v)(\alpha+\mu)(\delta+\mu)}, \\
\frac{\mu(1-v)-(\mu+v)(\alpha+\mu)(\delta+\mu)}{(1-v)(\alpha+\mu)(\delta+\mu)} \\
\frac{v(\alpha+\mu)^{2}(+)^{2}+(1-v) \alpha \delta \mu-(v+\mu)(\alpha+\mu)(\delta+\mu) \alpha \delta}{(1-v)(\alpha+\mu)(\delta+\mu) \alpha \mu}
\end{array}\right)
$$

Based on the equations (5)-(8), the Jacobian matrices are:

$$
J=\left[\begin{array}{cccc}
-(v+\mu+(1-v) I) & 0 & 0 & 0 \\
(1-v) I & -(\alpha+\mu) & 0 & 0 \\
0 & \alpha & -(\delta+\mu) & 0 \\
v & 0 & \delta & -\mu
\end{array}\right]
$$


Then find the eigen value of the Jacobian matrix in equation (15) with substituting the $K_{0}=(S, E, I, R)=$ $\left(\frac{\mu}{\mu+v}, 0,0, \frac{v}{\mu+v}\right)$ value into the $J$ matrix, so we get:

$$
\begin{aligned}
& J\left(K_{0}\right)=\left[\begin{array}{cccc}
-(v+\mu) & 0 & 0 & 0 \\
0 & -(\alpha+\mu) & 0 & 0 \\
0 & \alpha & -(\delta+\mu) & 0 \\
v & 0 & \delta & -\mu
\end{array}\right] \\
& \left|\lambda I-\left(J\left(K_{0}\right)\right)\right|=0 \\
& \begin{array}{cccc}
\lambda+(v+\mu) & 0 & 0 & 0 \\
0 & \lambda+(\alpha+\mu) & 0 & 0 \\
0 & \alpha & \lambda+(\delta+\mu) & 0 \\
v & 0 & \delta & \lambda+\mu
\end{array} \mid=0
\end{aligned}
$$

From the characteristic equations, we obtained the eigen values from the $J\left(K_{0}\right)$ matrix, are:

$$
\begin{aligned}
& \lambda_{1}=-(v+\mu) \\
& \lambda_{2}=-(\alpha+\mu) \\
& \lambda_{3}=-(\delta+\mu) \\
& \lambda_{4}=-\mu
\end{aligned}
$$

With $v, \alpha, \mu, \delta>0$ then the eigen values that we get ${ }_{1,2},,_{3}, 4$ are negative, so that the free-disease equilibrium point is stable global asymptotic. Substitute the value of $K_{e}=\left(S^{*}, E^{*}, I^{*}, R^{*}\right)$

$$
K_{e}=\left(\begin{array}{c}
\frac{(\alpha+\mu)(\delta+\mu)}{(1-v) \alpha}, \frac{(\delta+\mu)(\mu(1-v) \alpha+(\mu+v)(\alpha+\mu)(\delta+\mu)}{\alpha(1-v)(\alpha+\mu)(\delta+\mu)} \\
\frac{\mu(1-v)-(\mu+v)(\alpha+\mu)(\delta+\mu)}{(1-v)(\alpha+\mu)(\delta+\mu)}, \\
\frac{v(\alpha+\mu)^{2}(+)^{2}+(1-v) \alpha \delta \mu-(v+\mu)(\alpha+\mu)(\delta+\mu) \alpha \delta}{(1-v)(\alpha+\mu)(\delta+\mu) \alpha \mu}
\end{array}\right)
$$

Into the J matrix, then obtained:

$$
J\left(K_{e}\right)=\left[\begin{array}{cccc}
-A & 0 & 0 & 0 \\
B & -(\alpha+\mu) & 0 & 0 \\
0 & \alpha & -(\delta+\mu) & 0 \\
v & 0 & \delta & -\mu
\end{array}\right]
$$

Where $A=\left(v+\mu+\frac{\mu(1-v)-(\mu+v)(\alpha+\mu)(\delta+\mu)}{(\alpha+\mu)(\delta+\mu)}\right), B=\frac{\mu(1-v)-(\mu+v)(\alpha+\mu)(\delta+\mu)}{(\alpha+\mu)(\delta+\mu)}$

The eigen value of $J\left(K_{e}\right)$ matrix can be found by determine the det of $\left(J\left(K_{e}\right)-\lambda I\right)=0$ with $\lambda$ is the eigen value and $I$ is matrix identity. Then obtained:

$$
\left|\begin{array}{cccc}
\lambda+A & 0 & 0 & 0 \\
-B & \lambda+(\alpha+\mu) & 0 & 0 \\
0 & -\alpha & \lambda+(\delta+\mu) & 0 \\
-v & 0 & -\delta & \lambda+\mu
\end{array}\right|=0
$$

Form the characteristic equations we get the eigen values from $J\left(K_{e}\right)$ matrix, that are:

$$
\begin{aligned}
& \lambda_{1}=-A \\
& \lambda_{2}=-(\alpha+\mu) \\
& \lambda_{3}=-(\delta+\mu) \\
& \lambda_{4}=-\mu
\end{aligned}
$$

Where

$$
A=\left(v+\mu+\frac{\mu(1-v)-(\mu+v)(\alpha+\mu)(\delta+\mu)}{(\alpha+\mu)(\delta+\mu)}\right)
$$

With $A, \alpha, \mu, \delta>0$ then the eigen values ${ }_{1,2},,_{3}, 4$ are negative so that the free-disease equilibrium point is stable global asymptotic. 
d. The Basic Reproduction Number $\left(R_{0}\right)$ of The Impact of Distributing Vaccines toward The Spread of COVID-19

The basic reproduction number $\left(R_{0}\right)$ is determined using the matrices generation method, based on equations (6) and (7), then obtained:

$$
\begin{aligned}
& \frac{d E}{d t}=(1-v) I S-(\alpha+\mu) E \\
& \frac{d I}{d t}=\alpha E-(\delta+\mu) I
\end{aligned}
$$

Definite $\varphi=\left[\begin{array}{c}(1-v) I S \\ 0\end{array}\right]$ and $\psi=\left[\begin{array}{c}(\alpha+\mu) E \\ (\delta+\mu) I-\alpha E\end{array}\right]$ where $\varphi$ as the matrix from the rate of the new infected individuals and $\psi$ is the matrix of the rate of change of death and recovery that are deducted the infection class.

Matrix Next Generation in $K_{0}$ point:

$$
\begin{aligned}
& F=\left[\begin{array}{cc}
0 & (1-v) I S \\
0 & 0
\end{array}\right]=\left[\begin{array}{cc}
0 & \frac{\mu(1-v)}{\mu+v} \\
0 & 0
\end{array}\right] \\
& V=\left[\begin{array}{cc}
(\alpha+\mu) & 0 \\
-\alpha & (\delta+\mu)
\end{array}\right] \\
& V^{-1}=\frac{1}{(\alpha+\mu)(\delta+\mu)}\left[\begin{array}{cc}
(\delta+\mu) & 0 \\
\alpha & (\alpha+\mu)
\end{array}\right]=\left[\begin{array}{cc}
\frac{1}{(\alpha+\mu)} & 0 \\
\frac{\alpha}{(\alpha+\mu)(\delta+\mu)} & \frac{1}{(\delta+\mu)}
\end{array}\right] \\
& F V^{-1}=\left[\begin{array}{cc}
0 & \frac{\mu(1-v)}{\mu+v} \\
0 & 0
\end{array}\right]\left[\begin{array}{cc}
\frac{1}{(\alpha+\mu)} & 0 \\
\frac{\alpha}{(\alpha+\mu)(\delta+\mu)} & \frac{1}{(\delta+\mu)}
\end{array}\right] \\
& F V^{-1}=\left[\begin{array}{cc}
\frac{\mu(1-v)}{(\alpha+\mu)(\delta+\mu)(\mu+v)} & \frac{\mu(1-v)}{(\delta+\mu)(\mu+v)} \\
0 & 0
\end{array}\right]
\end{aligned}
$$

$R_{0}$ is taken by the highest absolute value, then obtained:

$$
\begin{aligned}
& R_{0}=\frac{\mu(1-v)}{(\delta+\mu)(\mu+v)} ;(\alpha+\mu) \geq 1 \\
& R_{0}=\frac{\mu(1-v)}{(\alpha+\mu)(\delta+\mu)(\mu+v)} ; 0<(\alpha+\mu)<1
\end{aligned}
$$

\section{Numerical Simulation of The SEIR Model of The Impact of Distributing Vaccine Toward The Spread of COVID-19 in Kabupaten Gowa}

The model simulations are performed using the Maple 18 software. The initial values of $S(0), E(0), I(0), R(0)$ and parameter values of the models used in this simulation are presented in Table 2, Table 3, and Table 4, with the basic reproduction number values $R_{0}$ obtained based on equation (30) is $\frac{\mu(1-v)}{(\alpha+\mu)(\delta+\mu)(\mu+v)}$.

Table 2. The Initial Values of SEIR Model of The Impact of Distributing Vaccines Toward The Spread of COVID-19

\begin{tabular}{ccc}
\hline Variables & Estimated Values & Sources \\
\hline S $(0)$ & 768735 & m.andrafarm.com \\
E (0) & 3468 & m.andrafarm.com \\
I (0) & 2578 & m.andrafarm.com \\
R (0) & 2219 & m.andrafarm.com \\
N (0) & 777000 & m.andrafarm.com \\
\hline
\end{tabular}


Table 3. Parameter Values of SEIR Model of The Impact of Distributing Vaccines Toward The Spread of COVID-19

\begin{tabular}{ccc}
\hline Parameters & Estimated Values & Sources \\
\hline$\alpha$ & 0.005984513085 & m.andrafarm.com \\
$\delta$ & 0.00643099041 & m.andrafarm.com \\
$\mu$ & 0.014 & m.andrafarm.com \\
\hline
\end{tabular}

Table 4. Assumption Parameter Values of The SEIR Model of The Impact of Distributing Vaccines Toward The Spread of COVID-19

\begin{tabular}{cccc}
\hline Parameter & Simulation 1 & Simulation 2 & Simulation 3 \\
\hline $\mathrm{v}$ & $10 \%$ & $50 \%$ & $90 \%$ \\
\hline
\end{tabular}

\section{Numerical Simulation Results of The Impact of Distributing Vaccines toward The Spread of COVID-19}

The value of equilibrium points of The SEIR model is determined by substituting the parameter values (simulation 1) in Table 3 and Table 4 on equations (9)-(12), which are equated with zero, then obtained:

$$
\left\{\begin{array}{l}
(0.014-(0.114+0.9 I) S=0 \\
0.9 I S-0.01998451308 E=0 \\
0.005984513085 E-0.02043099041 I=0 \\
0.00643099041 I+0.1 S-0.014 R=0
\end{array}\right.
$$

The equation system (32) provides the equilibrium points of the endemic SEIR Model, namely:

$$
(S, E, I, R)=(0.0758074103,0.268105367,0.0785316838,0.577555538)
$$

These equilibrium points explain that the number of human population that are susceptible to COVID-19 was $7.5 \%$, exposed is $26 \%$, infected is $7.8 \%$ and those recovered is $57 \%$ from the total 770.000 human population.

The eigen values based on the equations (18)-(21) with the parameter values in Table 3 and Table 4 for The Impact of Distributing Vaccines toward The Spread of COVID-19 SEIR model are:

$$
\lambda_{1}=-0.014, \lambda_{2}=-0.01998451308, \lambda_{3}=-0.02043099041, \lambda_{4}=-0.014
$$

With the same way, the equilibrium values and eigen values for simulation 2 and simulation 3 are written in Table 5. The eigen values obtained are real and negative, the type of stability analysis at this equilibrium point is asymptotic stable.

The basic reproduction number $R_{0}$ for the endemic case of COVID-19 from the equation (32) with only $10 \%$ vaccination is $R_{0}=5.409738518$. This is mean that, if a person is infected with COVID-19 it will infect to 5 other people. Whereas the $R_{0}$ for simulation 2 and simulation 3 that are presented in Table 5 explain that $50 \%$ vaccination and $100 \%$ vaccination will reduce the spread of COVID-19 and does not cause spreading of COVID-19 in Kabupaten Gowa.

Table 5. The Equilibrium Points Value, Eigen Values, and $R_{0}$ Value

\begin{tabular}{cccccccccc}
\hline Simulasi & $\lambda_{1}$ & $\lambda_{2}$ & $\lambda_{3}$ & $\lambda_{4}$ & $S^{*}$ & $E^{*}$ & $I^{*}$ & $R^{*}$ & $R_{0}$ \\
\hline 1 & -4.88987 & -0.01998 & -0.02043 & -0.014 & 0.07580 & 0.26810 & 0.07853 & 0.57755 & 5.40973 \\
2 & -0.514 & -0.01998 & -0.02043 & -0.014 & 0.27237 & 0 & 0 & 0.97276 & 0.66656 \\
3 & -0.914 & -0.01998 & -0.022043 & -0.014 & 0.15317 & 0 & 0 & 0.98468 & 0.07497 \\
\hline
\end{tabular}

\section{Simulation 1: SEIR Model for The Impact of Distributing Vaccines Toward The Spread of COVID-19 in Kabupaten Gowa}

Numerical simulation to determine the effect of vaccines on the dynamics of the number of Exposed and Infected the spread of COVID-19 in Kabupaten Gowa. The simulation uses the initial values in Table 2 and the parameters in Table 3 with the vaccination $10 \%$ on Susceptible populations. 


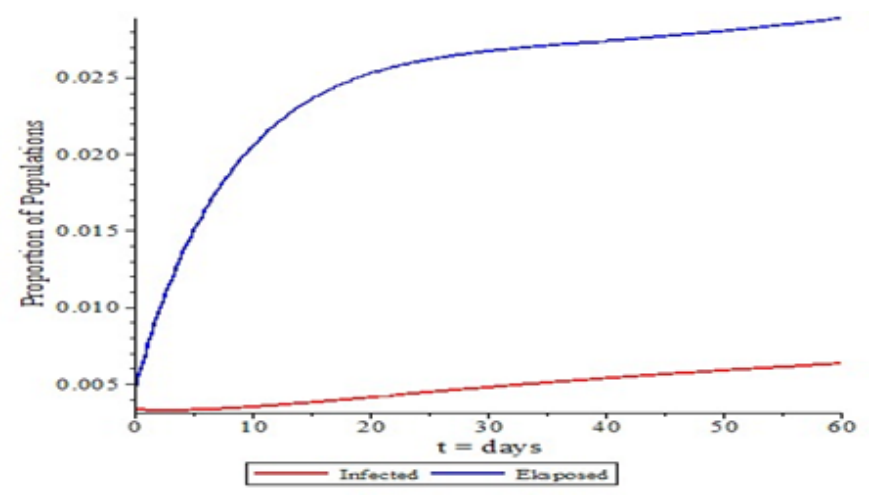

Figure 3. The Variation in Number of Populations in Exposed and Infected with The Effectiveness of The Vaccine is $10 \%$

Based on the Figure 3, show that the Exposed and Infected populations increasing over the time and does not show the existence of decreasing, it means that the pandemic of COVID-19 is happening.

Simulation 2: SEIR Model for The Impact of Distributing Vaccines Toward The Spread of COVID-19 in Kabupaten Gowa

Numerical simulation to determine the effect of vaccines on the dynamics of the number of Exposed and Infected the spread of COVID-19 in Kabupaten Gowa. The simulation uses the initial values in Table 2 and the parameters in Table 3 with the vaccination $50 \%$ on Susceptible populations.

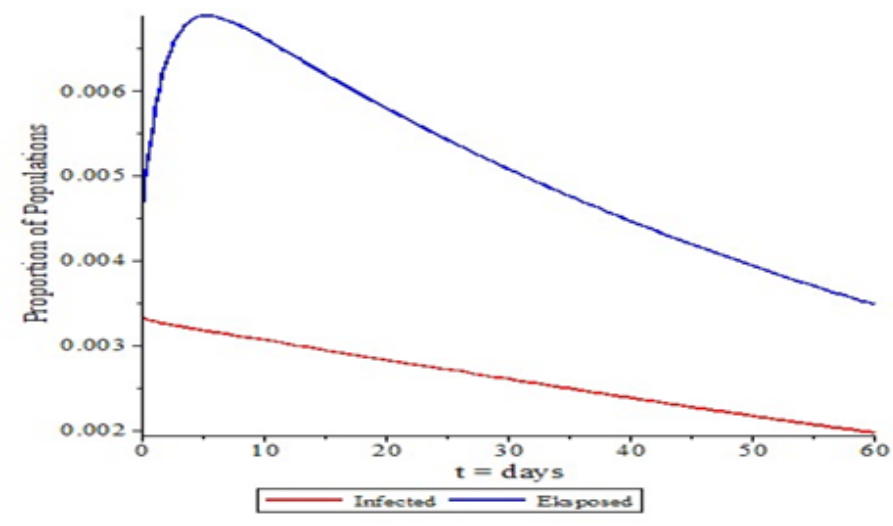

Figure 4. The Variation in Number of Populations in Exposed and Infected with The Effectiveness of The Vaccine is 50\%

Based on the Figure 4, the Infected populations graph experiences a continuously decreased number of cases till reach the 0 infected case on day 120. Even though for the Exposed populations have time to experience an increased number of cases, but on the 10th day it reached out the decreased. It showed that the populations in Kabupaten Gowa can be free from the spread of COVID-19.

\section{Simulation 3: SEIR Model for The Impact of Distributing Vaccines Toward The Spread of COVID-19 in Kabupaten Gowa}

Numerical simulation to determine the effect of vaccines on the dynamics of the number of Exposed and Infected the spread of COVID-19 in Kabupaten Gowa. The simulation uses the initial values in Table 2 and the parameters in Table 3 with the vaccination $90 \%$ on Susceptible populations. 


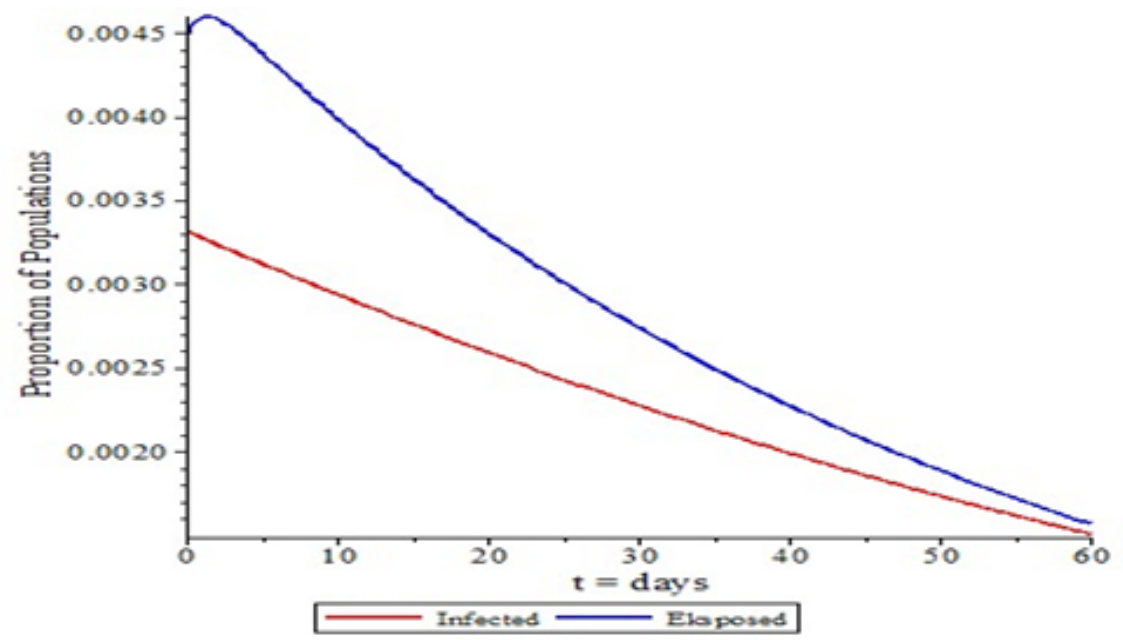

Figure 5. The Variation in Number of Populations in Exposed and Infected with The Effectiveness of The Vaccine is $90 \%$

Based on the Figure 5, the number of Exposed and Infected populations decreasing as time goes by until it reaches out at the 0 point.

The research result of the transmission of COVID-19 by mathematics model (Annas et al., 2020) delivers a transmission of the COVID-19 SEIR Model and then the stability analysis of the model and the prediction the number of COVID-19 cases simulations in Indonesia with the effect of vaccinations. The research by (Abdy et al., 2021) using Fuzzy approach after construct the SIR Model of the spread of COVID-19 in Indonesia, meanwhile the result of this research construct a SEIR Model on the spread of COVID-19 with the effect of vaccination in Kabupaten Gowa show that if the effectiveness of the vaccines are high and the number of people in Kabupaten Gowa that already had vaccinated is high, then the number of the spread of COVID-19 in Kabupaten Gowa are getting smaller so that cause no more spreads of COVID-19, and the pandemic is over.

\section{E. CONCLUSION AND SUGGESTION}

Based on the result of this study, we concluded that this mathematics SEIR model can be used to illustrate the impact of distributing vaccines toward the spread of COVID-19 in Kabupaten Gowa. The analysis and simulation results model of SEIR model of the distributing vaccines toward the spread of COVID-19 in Kabupaten Gowa showed that the higher the effectiveness of the vaccines and the number of the population in Kabupaten Gowa that already had vaccinated is high, then showed no more spreads of COVID-19, so that the pandemic is over.

\section{ACKNOWLEDGEMENT}

We would like to thank The Ministry of Education, Culture, Research, and Technology for the financial support. Also we would like to thank The Ministry of Health for helping us providing the data that we need in this research.

\section{REFERENCES}

Abdy, M., Side, S., Annas, S., Nur, W., and Sanusi, W. (2021). An SIR Epidemic Model for COVID-19 Spread with Fuzzy Parameter: The Case of Indonesia. Advances in Difference Equations, 2021(1).

Afifah, B. (2021). Mengenal Perkembangan Vaksin COVID-19, UNAIR News. http://news.unair.ac.id/2021/01/11/ mengenal-perkembangan-vaksin-covid-19/.

Annas, S., Isbar Pratama, M., Rifandi, M., Sanusi, W., and Side, S. (2020). Stability Analysis and Numerical Simulation of SEIR Model for Pandemic COVID-19 Spread in Indonesia. Chaos, Solitons and Fractals, 139:110072.

Aulia, N., Kharis, M., and Supriyono, S. (2016). Pemodelan Matematika Epidemi Influenza dengan Memperhatikan Peluang Keberhasilan Vaksinasi dan Kekebalan Tetap. Unnes Journal of Mathematics, 5(2):190-200. 
Han, Y. and Yang, H. (2020). The Transmission and Diagnosis of 2019 Novel Coronavirus Infection Disease (COVID19): a Chinese Perspective. Journal of medical virology, 92(6):639-644.

KPCN (2021). Data Vaksinasi Covid-19 (Update per 6 Februari 2021), Satuan Tugas Penanganan Covid-19.

Liu, C., Zhou, Q., Li, Y., Garner, L. V., Watkins, S. P., Carter, L. J., Smoot, J., Gregg, A. C., Daniels, A. D., Jervey, S., and Albaiu, D. (2020). Research and Development on Therapeutic Agents and Vaccines for COVID-19 and Related Human Coronavirus Diseases. ACS Central Science, 6(3):315-331.

Ophinni, Y., Hasibuan, A. S., Widhani, A., Maria, S., Koesnoe, S., Yunihastuti, E., Karjadi, T. H., Rengganis, I., and Djauzi, S. (2020). COVID-19 Vaccines: Current Status and Implication for Use in Indonesia. Acta Medica Indonesiana, 52(4):388-412.

Pang, J., Wang, M. X., Ang, I. Y. H., Tan, S. H. X., Lewis, R. F., Chen, J. I., Gutierrez, R. A., Gwee, S. X. W., Chua, P. E. Y., Yang, Q., Ng, X. Y., Yap, R. K., Tan, H. Y., Teo, Y. Y., Tan, C. C., Cook, A. R., Yap, J. C. H., and Hsu, L. Y. (2020). Potential Rapid Diagnostics, Vaccine and Therapeutics for 2019 Novel Coronavirus (2019-nCoV): A Systematic Review. Journal of Clinical Medicine, 9(3).

Resmawan, R., Nuha, A. R., and Yahya, L. (2021). Analisis Dinamik Model Transmisi COVID-19 dengan Melibatkan Intervensi Karantina. Jambura Journal of Mathematics, 3(1):66-79.

Sifriyani, S. and Rosadi, D. (2020). Susceptible Infected Recovered (Sir) Model for Estimating Covid-19 Reproduction Number in East Kalimantan and Samarinda. Media Statistika, 13(2):170-181.

Sulsel Tanggap Covid-19 (2021). Data Pantauan Covid-19 di Sulawesi Selatan. https://covid19.sulselprov.go.id/data.

WHO (2021). WHO Coronavirus (Covid-19) Dashboard. https://covid19.who.int/. 
